\title{
New Fragments from Rufus of Ephesus' On Melancholy (24a-d) and On Preferring Fresh Poppies
}

\section{DOI:}

$10.1017 /$ S0009838819000521

\section{Document Version}

Accepted author manuscript

Link to publication record in Manchester Research Explorer

\section{Citation for published version (APA):}

Pormann, P. (2019). New Fragments from Rufus of Ephesus' On Melancholy (24a-d) and On Preferring Fresh Poppies. The Classical Quarterly. https://doi.org/10.1017/S0009838819000521

\section{Published in:}

The Classical Quarterly

\section{Citing this paper}

Please note that where the full-text provided on Manchester Research Explorer is the Author Accepted Manuscript or Proof version this may differ from the final Published version. If citing, it is advised that you check and use the publisher's definitive version.

\section{General rights}

Copyright and moral rights for the publications made accessible in the Research Explorer are retained by the authors and/or other copyright owners and it is a condition of accessing publications that users recognise and abide by the legal requirements associated with these rights.

\section{Takedown policy}

If you believe that this document breaches copyright please refer to the University of Manchester's Takedown Procedures [http://man.ac.uk/04Y6Bo] or contact uml.scholarlycommunications@manchester.ac.uk providing relevant details, so we can investigate your claim.

\section{OPEN ACCESS}


New Fragments from Rufus of Ephesus'

On Melancholy (24a-d) and On Preferring Fresh Poppies ${ }^{1}$

Rufus of Ephesus (fl. ca. A.D 100) wrote a large body of works on a variety of medical topics..$^{2}$ Generally speaking, the Arabic tradition is particularly important for the reconstruction of much of his oeuvre. ${ }^{3}$ In the present article, I am going to present four new fragments of Rufus' On Melancholy and a fragment from an otherwise unknown monograph On Preferring Fresh Poppies. These new fragments provide fascinating new insights into Rufus' approach to recording case histories.

Rufus' On Melancholy in two books was translated into Arabic some time in the ninth century. The Greek text and the Arabic translation have not come down to us in their entirety, but survive in later quotations in authors such as Aëtius of Amida (fl. c. 500-550) and Abū Bakr Muhammad ibn Zakariyā’ al-Rāzī (d. ca. 925). ${ }^{4}$ We have a few Latin fragments, based on the Arabic translation, and, as Fischer has shown, on the Greek text as well.5 Moreover, a number of new Arabic

1 This article is a product of the ERC-funded project 'Arabic Commentaries on the Hippocratic Aphorisms' (ARABCOMMAPH, ERC-2011-StG_20101124). The author would like to thank all the team members, and in particular, Kamran I. Karimullah, Taro Mimura, and Hammood Obaid.

2 See A. Sideras, 'Rufus von Ephesos und sein Werk im Rahmen der antiken Welt', ANRW 2.37.2 (1994), 1080-1253.

3 M. Ullmann, 'Die arabische Überlieferung der Schriften des Rufus von Ephesos', ANRW 2.37.2 (1994), 1293-1349.

4 P.E. Pormann, Rufus of Ephesus, On Melancholy, SAPERE 12 (Tübingen, 2008).

5 K.-D. Fischer, 'De fragmentis Herae Cappadocis atque Rufi Ephesii hactenus ignotis', Galenos 4 (2010), 173-83, at 180-83. 
fragments have come to light ${ }^{6}$ Rufus adhered to the idea of humoral pathology as developed in the Hippocratic treatise On the Nature of Man; and black bile, one of the four humours, obviously played a major role in his conception of melancholy. The new fragments collected here illustrate two facets of Rufus' approach to medicine that have recently come into clearer focus: the dialogue with the patient; 7 and the relationship between physiological and psychic events. ${ }^{8}$ The four new fragments presented here deal with the case of a patient who, owing to a bout of melancholy, does not feel pain, not even when the searing heat of a cautery iron burns his flesh.

The new fragments all come from Arabic commentaries on the Hippocratic Aphorisms. ${ }^{9}$ Briefly, we have a dozen commentaries in Arabic on this text, dating from the eleventh to the fifteenth century A.D. It is a complex exegetical tradition in which later commentators often rely on earlier ones, although, naturally, they also criticise their predecessors and modify common sources. The four fragments illustrate one aspect of this tradition, namely how a quotation to which at least one commentator still had direct access in Arabic was reshaped and modified by

$6 \quad$ P.E. Pormann, 'New Fragments from Rufus of Ephesus' On Melancholy', CQ 64 (2014), 649-56.

$7 \quad$ For a recent study of Rufus' technique to interact with patients and question them, see M. Letts, 'Rufus of Ephesus and the Patient's Perspective in Medicine', British Journal for the History of Philosophy 22 (2014), 996-1020; and ead., 'Questioning the Patient, Questioning Hippocrates: Rufus of Ephesus and the Pursuit of Knowledge', in G. Petridou and C. Thumiger (edd.), Homo Patiens - Approaches to the Patient in the Ancient World (Leiden and Boston, 2016), 81-103.

$8 \quad$ E.g., P.E. Pormann, 'Medical Epistemology and Melancholy: Rufus of Ephesus and Miskawayh', in W. V. Harris (ed.), Mental Disorders in the Classical World, Columbia Studies in the Classical Tradition 38 (Leiden, 2013), 223-43.

$9 \quad$ For a survey of the whole tradition, see P.E. Pormann, and K. Karimullah, 'The Arabic Commentaries on the Hippocratic Aphorisms: Introduction', Oriens 45 (2017), 1-52, updating and expanding P.E. Pormann and N.P. Joosse, 'Commentaries on the Hippocratic Aphorisms in the Arabic Tradition: The Example of Melancholy', in P.E Pormann (ed.), Epidemics in Context: Greek Commentaries on Hippocrates in the Arabic Tradition, Scientia Graeco-Arabica 8 (Berlin, 2012), 211-49. 
later exegetes. Moreover, the later Arabic sources also provide secondary evidence for the textual state of the tradition.

Manfred Ullmann had already identified one fragment relating to this episode more than twenty years ago, and I subsequently included it in my collections of fragments from Rufus' On Melancholy as F24.10 It is taken from The Clear Guide on How to Treat Patients (al-Kitāb al-Wādih al-dalīl fì mudāwāt al-'alı̄l) by Muhammad ibn 'Alī ibn 'Abd Allāh al-Tawahhumī, an author about whom nothing is known, and runs as follows: 11

[1] Rufus said: 'I cauterised someone who suffered from this ailment [melancholy] with a hot knife. [2] I put it onto one of the parts [of his body], but he [the patient] did not feel the fire. [3] He then said: 'Increase your fire; it is cold' 12 , for the sensation had ceased. [4] There were many ulcers on his legs, since the blackness had reached the lower part of the body, because of the frequent motion of the legs.'

Three additional fragments all come from commentaries on aphorism 7.40, which runs as follows in Greek and Arabic13:

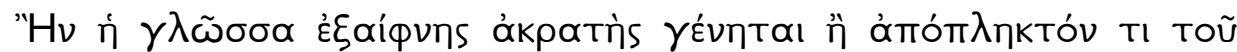

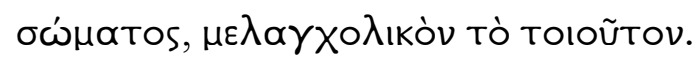

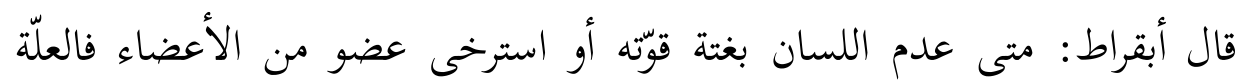

$10 \quad$ Ullmann (n. 2), 1316.

$11 \quad$ Ed. and tr. Pormann (n. 1), 42-3.

12 I have here revised my earlier translation, as I misunderstood the antecedent of 'innaha ('it is'); it must refer to the fire.

13 Greek text edited by C. Magdelaine, 'Histoire du texte et édition critique, traduite et commentée, des Aphorismes d'Hippocrate', 3 vols. (Diss., Université Paris-Sorbonne, 1994), $2.466-7$. 
Hippocrates said: when the tongue suddenly loses its power or a part of the body becomes limb (istarh $\bar{a})$, then the disease is melancholic.

The first extant exegete to mention Rufus when commenting on this aphorism is Ibn Abī Ṣādiq. He died after 1068 and was called the 'second Hippocrates (Buqrāt al-tâñ̄)', owing to the fame of his Commentary on Hippocrates' 'Aphorisms' (Šarḥ Fuṣūl Buqrāț), which survives in more than forty manuscripts. ${ }^{14} \mathrm{He}$ begins his commentary on this lemma with an explanation of the verb istarha $\bar{a}$, which here means 'to lose sensation and movement (fuqdān alhiss wa-l-haraka)'. He then criticises Galen for being wrong about the aetiology of this phenomenon: it is not caused by black bile or phlegm, but by a hard swelling and bad mixture. Ibn Abī Ṣādiq then says (F24a)15:

$$
\begin{aligned}
& \text { [1] وافهم أنّ الروح الحسّاس إذا خالطه البخار الغليظ السوداوي امتنع من النفوذ }
\end{aligned}
$$

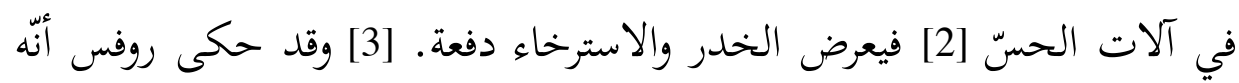

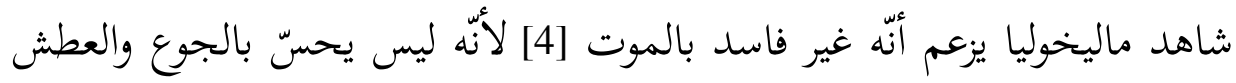

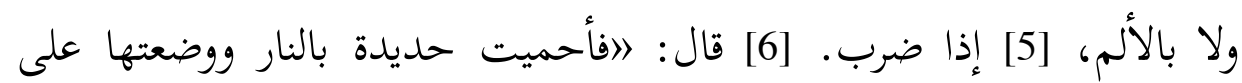

$$
\begin{aligned}
& \text { ساعده. [7] فاحتملها زماناً طويلاً بقول: [8] >ذِدني كَيّك، [9] فإنّ نارك باردة). }
\end{aligned}
$$

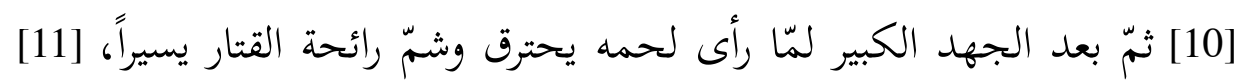

$$
\begin{aligned}
& \text { انتبه على أنّ ما قاله كاذب. } \\
& \text { [12] وأيضاً فإنّأ السوداء لغلظها وأرضيتها تصلب العصب وتفعل فيه جسواً }
\end{aligned}
$$

14 Pormann and Karimullah (n. 9), at 18-19.

15 Edition by P.E. Pormann et al., 'Al-Maqāla al-sābi' a min Šarḥ Fuṣūl Abuqrāṭ li-bn Abī Șādiq’, University of Manchester, Manchester. DOI: 10.3927/51932414. CB1: fol. 216a, line 10-fol. 217b, line 6; V1: fol. 87a, line 24-fol. 87b, line 1.

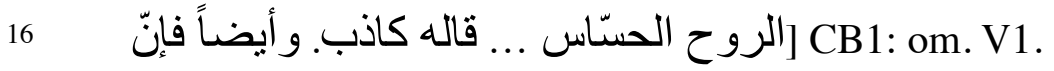

17 جسواً] V1: om. CB1. 


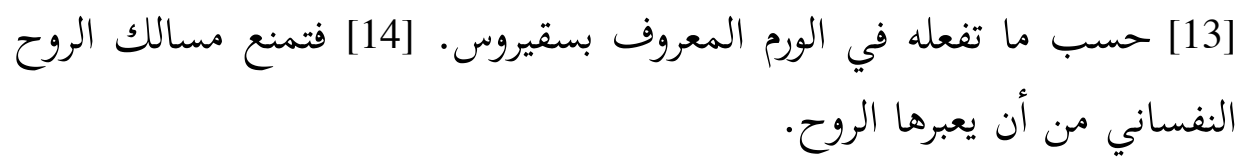

[1] Know that when the sensing pneuma (al-rūh al-hassās) is mixed with thick melancholic vapour, it is prevented from penetrating to the organs of sensation. [2] This then results in sudden numbness (hadar) and limpness (istirh $\vec{a})$. [3] Rufus recounted that he witnessed that a melancholic believed that he was incorruptible by death, [4] because he did not feel hunger, nor thirst, nor pain, [5] when he was hit. [6] $\mathrm{He}$ [Rufus] said: 'I heated a [cautery] iron in the fire and placed it on his forearm. [7] He bore it for a long time, saying: [8] "increase your cauterisation, [9] for your fire is cold". [10] Then, after a lot of effort, when he saw that his flesh was burning and smelled some odour of [flesh] being fried, [11] he realised that what he had said was false.'

[12] Also, because black bile is viscous and earthy, it hardens the nerves and produces hardness in them, [13] just as it does in the case of the swelling called skîros, [14] so that the pathways of the psychic pneuma are prevented from letting the pneuma pass through them.

This is by far the most complete version of our case history, and appears to contain some verbatim quotation from Rufus' On Melancholy, here put in inverted commas (§§6-11). In particular, although sharing some material with the fragment in al-Tawahhumī (F24), it is longer and more detailed.

Two other, later commentators mention Rufus in the context of commenting on aphorism 7.40 as well, but these two shorter fragments appear to be based on Ibn Abī Șādiq rather than presenting an independent tradition. In fact, the first commentator, al-Sinğārī̄, repeats quite a bit of Ibn Ab̄̄ Șādiq verbatim, without, 
however, acknowledging his source (F24b): 18

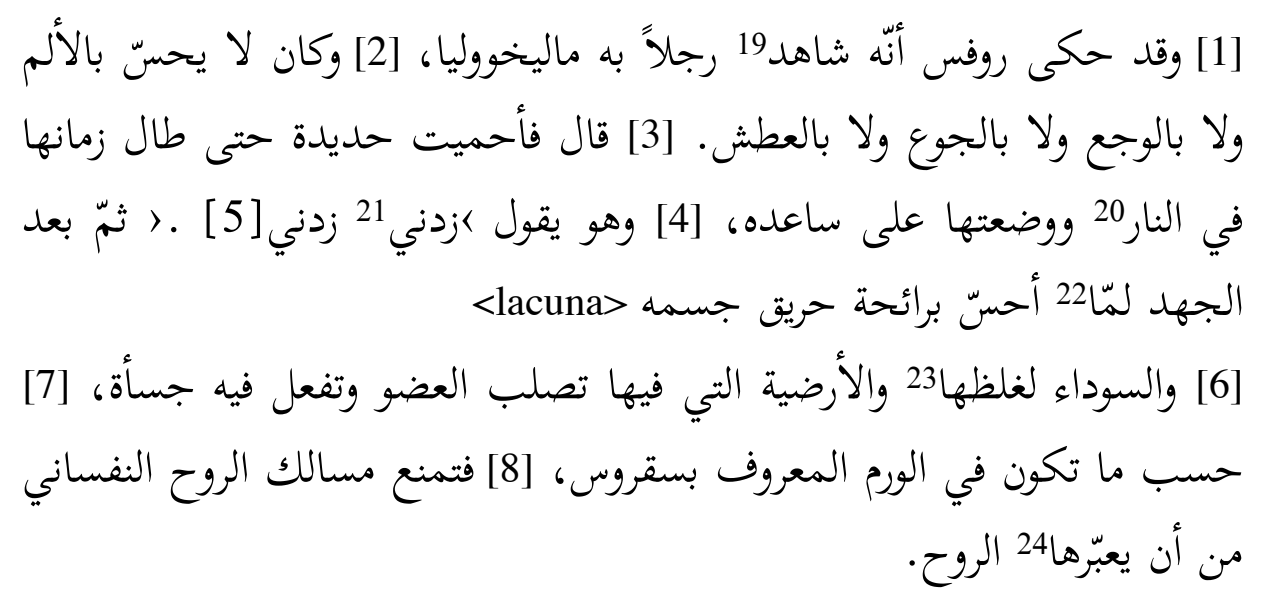

[1] Rufus recounted that he witnessed a man suffering from melancholy

[2] and he did not feel pain, nor ache, nor hunger, nor thirst. [3] $\mathrm{He}$

[Rufus] said: 'I heated a [cautery] iron in the fire for a long time, and put it on his forearm; [4] he was saying: "increase [it], increase [it]". [5]

18 Edition by P.E. Pormann et al., 'Al-Maqāla al-sābi 'a min Kitāb Tays̄̄r al-wușūl ilā tafsīr al-Fuṣūl li-Abuqrāṭ li-l-Sinğārī', University of Manchester, Manchester. DOI: 10.3927/52132613. The text is edited on the basis of two extant manuscripts: Aleppo, Fondation Salem, MS Ar. 1037 (henceforth G), fol. 126a, line 14-fol. 127a, line 2; and London, Wellcome Library, MS Or. 43 (henceforth W), fol. 74b, line 8- fol. 75a, line 1.

19 وشاهد : G. زي : شني G. حتى : حمى G. لغاضها G: لغلظها W. 
Then, after a lot of effort, when he sensed the odour of the body being burnt ... <lacuna>'.

[6] ... and black bile, because it is viscous and earthy, which hardens the part of the body and produces hardness in them, [7] just as it does in the case of the swelling called skîros, [8] so that the pathways of the psychic pneuma are prevented from letting the pneuma pass through them.

Whereas al-Sinğārī follows Ibn Ab̄̄ Șādiq quite closely in §§1-5 (corresponding to F24a $\S \S 3-7)$, he quotes him verbatim, but without acknowledgment in $\S \S 6-8$. Between $\S \S 5$ and 6, some text must have fallen out, as the comparison between the two authors clearly shows.

Al-Sīwāsī, an author of the early fourteenth century, also appears to rely on Ibn Abī Șādiq, although he provides merely a brief summary (F24c):25

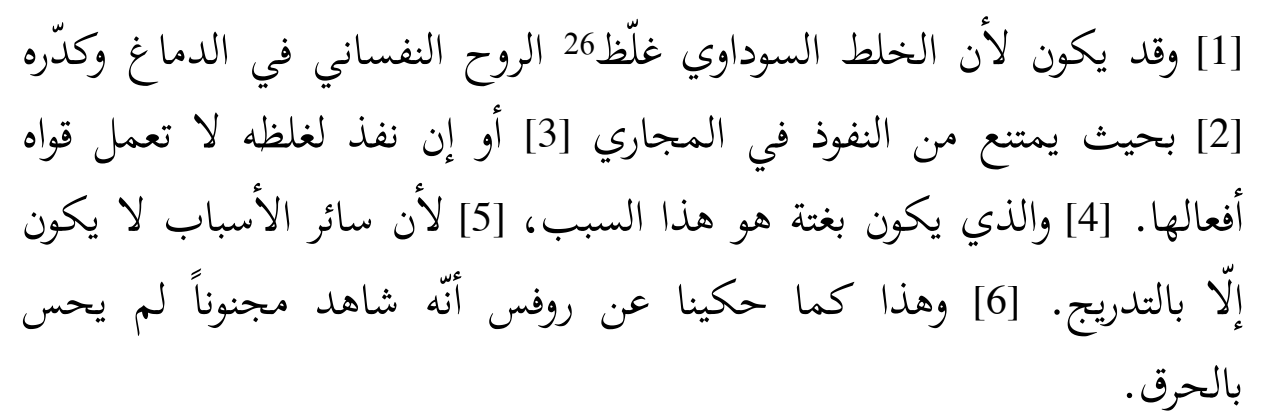

[1] It [loss of sensation] can also be caused by the melancholic humour making the psychic pneuma viscous and dark, [2] so that it is prevented

25 Edition by P.E. Pormann et al., 'Al-Maqāla al-sābi ' a min Kitāb 'Umdat al-Fuḥūl fì šarh al-Fuṣūl li-1-Sīwās̄̄', University of Manchester, Manchester. DOI: 10.3927/52136029. The text is edited on the basis of two extant manuscripts: Istanbul, Süleymaniye Kütüphanesi, Şehid Ali Paşa, MS 20451, fol. 50b, last line-fol. 51a, line 4 (S4); and Istanbul, Beyazid Devlet Kütüphanesi, MS Veliyeddin Efendi 2509, fol. 162b, lines 2-7 (V4).

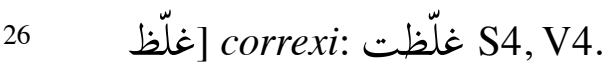


from penetrating through the passageways; [3] or even if it penetrates, its faculties do not carry out their functions because it is viscous. [4] What happens suddenly is due to the cause, [5] since the other causes only occur gradually. [6] This is as we have reported here on Rufus' authority, who witnessed that a madman did not feel being burnt.

Paragraphs 1-2 correspond to F24b $\S \S 1-2$, whereas $\S \S 3-5$ contain different material, partially summarising information in Ibn Abī Șādiq and Galen. The whole Rufus episode gets reduced to one short sentence $(\S 6)$.

Finally, we find a fragment in some of the manuscripts preserving Ibn Ab̄ Șādiq's commentary. The context is his commentary on aphorism 2.627:

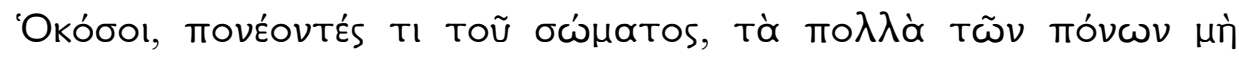

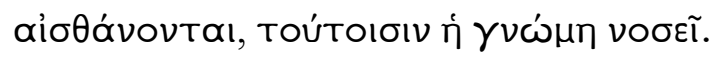

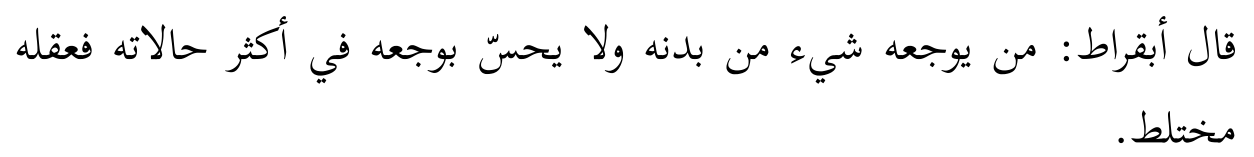

Hippocrates said: 'Those who suffer pain in some part of their body without feeling it in most cases, have a confused mind.

There are two different commentaries on this aphorism. In the majority of the manuscripts, Ibn Abī Șādiq explains this aphorism at some length by linking the faculty of intellection (al-qūwa al-'aqlīya) to the faculty of sensation (al-qūwa alhassāasa), as both are located in the same place, namely the brain. Let us call this version the main one. Yet in one manuscript (CB1), we find an alternate version after the main one which is introduced as follows: 'The writer of the original 
[manuscript] mentioned that during collation he found another commentary on this aphorism in a different manuscript. (Dakara kātibu l-aṣli annahū wağada fì nushati gayri l-aṣli waqta l-muqābalati šarḥan āhara li-hādā l-faṣli).28 Then follows the Hippocratic lemma and a full commentary, introduced by the word 'commentary (al-tafsīr)'. This alternate version is also preserved in another manuscript (S2), which lacks the main version.29 That these two versions circulated is probably due to the fact that Ibn Abī Șādiq revised his commentary. 30 In this alternate commentary on 2.6 , he linked this aphorism to melancholy, and especially to melancholic vapours rising to the brain. He also mentions religious melancholics who are too absorbed to feel pain. At the end of his commentary on this lemma, Ibn Abī Ṣādiq states (F24d) ${ }^{31}$ :

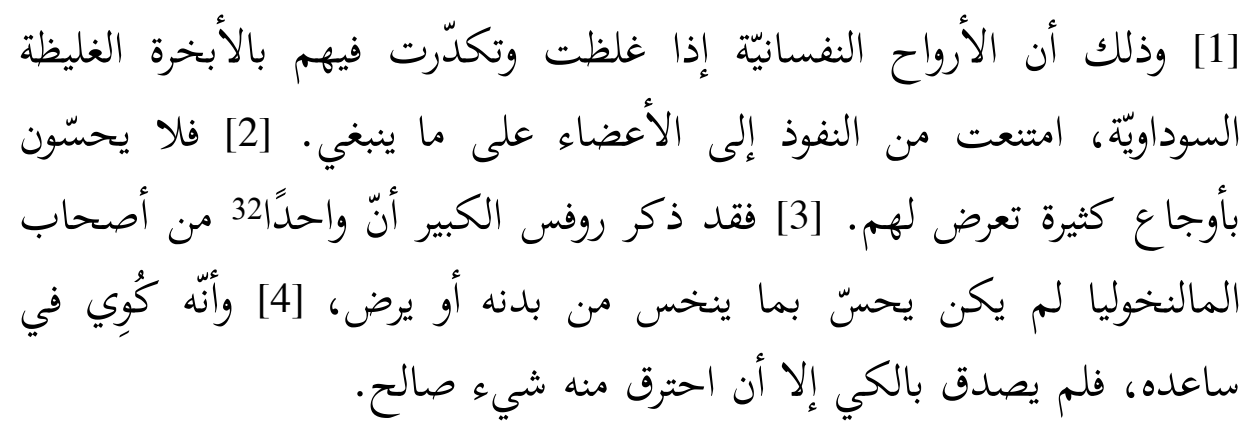

[1] For when psychic pneumas become viscous and turbid in them [sc.

28 Edition by P.E. Pormann et al., 'Al-Maqāla al-tāniya min Šarḥ Fuṣūl Abuqrāṭ li-bn Abī Șādiq', University of Manchester, Manchester. DOI: 10.3927/51931994, based on CB1 and V1. The note begins on CB1, fol. 26b, line 4 from the bottom-last.

29 Istanbul, Süleymaniye Kütüphanesi, MS Nuruosmaniye 3527 (henceforth S2). The 'alternate' commentary occurs on fol. 27a, line 1-fol. 27b, line 3.

$30 \quad$ Pormann and Karimullah (n. 9), at 11-13.

31 Pormann et al. (n. 28) ; CB1, fol. 27b, lines 4-9 and S2, fol. 27a, line 2 from the bottom-fol. 27b, line 3. I have collated S2, not used by Pormann et al. (n. 28), in order to produce a more sound and secure text.

32

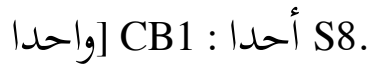


the patients] because of thick melancholic vapours, they are prevented from penetrating to the parts of the body as they should. [2] Then they do not sense many pains that befall them. [3] The great Rufus mentioned that one of those suffering from melancholy did not feel it when one pricked or prodded his body. [4] He [the patient] was cauterised at his forearm, but he did not believe that he was cauterized until a healthy part of his [body] burned.

This constitutes a shorter paraphrase of the longer version given by Ibn Abī Șādiq when commenting on aphorism $7.40(\mathrm{~F} 24 \mathrm{~b})$. Now that we have seen the various versions of this episode, we can draw some conclusions.

When one combines the four new fragments with the previously known F24, they offer quite a bit of new information. Clearly, F24a presents the fullest account, and we therefore have to assume that Ibn Abī Șādiq had either access to Rufus' On Melancholy in Arabic translation, or an intermediary source. There is still a small chance that this intermediary source could have been the Important Chapters on the Medicine of the Masters (Al-Fușül al-Muhimma fi tibb al'A'imma) by Sarābiyūn ibn Ibrāhīm (who can be dated to the eleventh century or later; not to be confused with Yuhannā ibn Sarābiyūn). ${ }^{33}$ It contains Rufus' Case Notes, and since these Case Notes are not complete, Ibn Abī Șādiq could presumably draw on the lost part here. It is more likely, though, that he draws on Rufus of Ephesus' On Melancholy.

We clearly see Rufus here talking about a specific case, an actual patient whom he treated. The patient labours under the illusion that he is immortal (F24a $\S 3)$; he does not feel hunger and thirst (F24a §4), nor pain when he is beaten

33 M. Ullmann, Rufus von Ephesus. Krankenjournale (Wiesbaden, 1978); see also E. Savage-Smith, A New Catalogue of Arabic Manuscripts in the Bodleian Library, University of Oxford. Volume I: Medicine (Oxford, 2011), no. 122 (pp. 471-5). 
(F24a $\S \S 4-5)$. The most striking consequence of this, however, is that fact that even when cauterised, the patient does not feel anything. He even asks to be cauterised more. Only the smell of his burning flesh alerts him to the fact that he is being burnt (F24a $\S \S 10-11)$. Moreover, his legs have ulcers, because the melancholic humour has descended there (F24 §4). The new fragments, and especially F24a, thus give us a more vivid and detailed picture of Rufus' melancholic patient who could not feel pain.

Moreover, the fragments illustrate nicely how a passage from an ancient author of great authority such as Rufus of Ephesus went through numerous mutations. The following scenario appears to be the most likely. When Ibn Abī Șādiq first commented on aphorism 2.6, he was not yet aware of Rufus' report of the melancholic not feeling pain. By the time he reached aphorism 7.40, he had sight of Rufus' On Melancholy, or possibly an intermediary source citing this episode. When Ibn Abī Șādiq then revised his commentary at a later state, he included this episode in his new commentary on aphorism 2.6. None of the subsequent commentators mentions it in the context of 2.6, which goes to show that the earlier version circulated much more widely and had a greater influence. It is from this earlier version that two later commentators drew when providing their explanation of 7.40. The older al-Sinğārī quotes Ibn Ab̄̄ Ṣādiq at times verbatim, although without acknowledgement. The younger al-Sīwāsī merely gives a short summary of the episode, taken most likely again from the earlier version of Ibn Abī Șādiq's commentary. Despite the vagaries of the transmission of Rufus' thought, the Arabic commentaries on the Aphorisms clearly constitute a rich source for otherwise lost Greek ideas. What is more, this source is now freely available under a creative commons licence, so that anybody can draw from it.

\section{Rufus' On Preferring Fresh Poppies}


The Hippocratic Treatments (al-Mu'ālağāt al-Buqrāțīya) by the tenth-century author al-Ṭabarī is another prominent source for quotations from ancient authors, not least from Rufus' On Melancholy. ${ }^{34}$ It contains a chapter 5.15 'On ear ache brought about by warm winds settling in the ears, and causing pain and tension', in which we find the following interesting quotation: 35

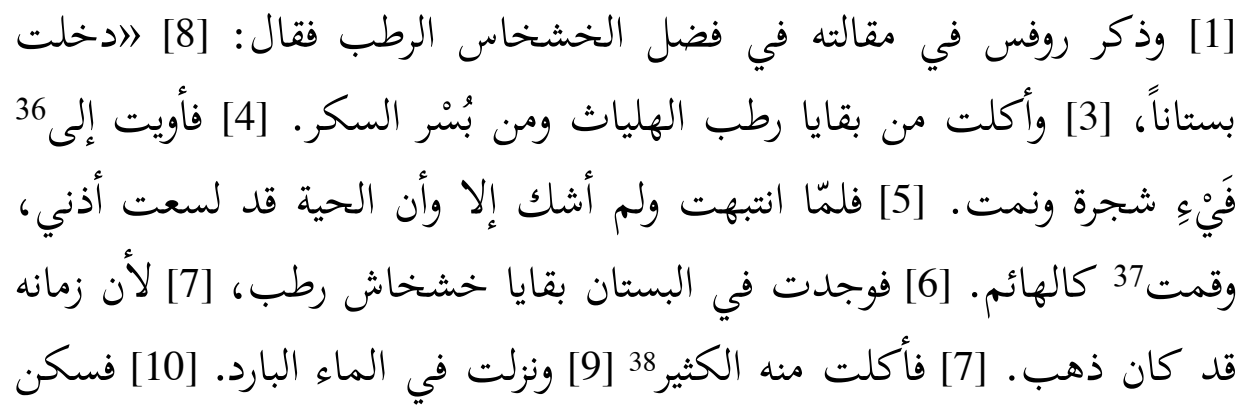

34 See L. Ambjörn, 'Book-Titles Mentioned in the 10th Century Medical Encyclopedia Al-Mu'ālajāt al-Buqrātịyya', Galenos 5 (2011), 103-11 and Pormann (n. 5), who collected new fragments from this source. On the author and treatise more generally, see now the very comprehensive assessment by E. Wakelnig, 'Al-TTabarī and al-Ṭabarī: Compendia between Medicine and Philosophy', in P. Adamson, and P.E. Pormann (edd.), Philosophy and Medicine in the Formative Period of Islam, Warburg Institute Colloquia 31 (London and Turin, 2017), 218-54.

35 Edited according to three manuscripts, namely 1) Teheran, Malik Millī Library, MS 4474, reproduced in facsimile by F. Sezgin, The Hippocratic Treatments: Al-Mu àlajāt alBuqrāțìya, 2 vols (Frankfurt, 1990) (henceforth MS T), 1:259, lines 9-14; 2) Oxford, Bodleian Library, MS Marsh 158, fol. 188b, lines 19-25 (henceforth MS O; see E. SavageSmith, A New Catalogue of Arabic Manuscripts in the Bodleian Library, University of Oxford. Volume I: Medicine [Oxford, 2011], item no. 48b, pp. 183-9); and 3) Munich, Bayerische Staatsbibliothek, MS Cod. arab. 810, fol. 305a (henceforth MS M), fol. 165b, line 9-14.

36 فأويتا لي : O, T.

37 [وقمت T : قمت M, O. 


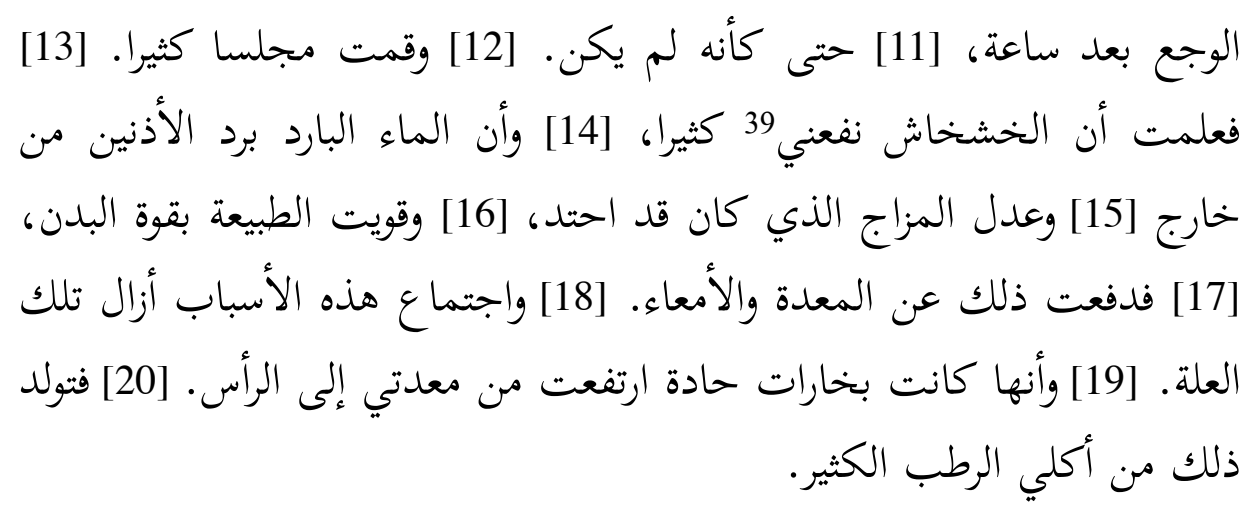

[1] In his treatise On Preferring Fresh Poppies, Rufus gave the following account: [2] 'I entered a garden [3] and ate the remnants of fresh figs [rațb al-hilayāt] and sweet figs [busr al-sukkar]. [4] I then repaired to the shade of a tree and slept. [5] When I awoke and I had no complaint other than that a snake had bit my ear, I rose like a madman. [6] I found remnants of fresh poppies in the garden, [7] because their season had just passed. [8] I ate a lot of them [9] and descended into cold water. [10] The pain subsided after a short while, [11] to the point that it nearly completely disappeared. [12] I frequently repeated these sessions. [13] Then I knew that the poppy had been greatly beneficial for me, [14] and that the cold water had cooled the ears from the outside [15] and improved the mixture that had become too sharp, [16] so that the nature was strengthened by the body being strong. [17] Then it [nature] pushed this [sc. the poppy] away from the stomach and the intestines. [18] The confluence of these causes removed this disease. [19] [I also learnt] that sharp vapours had risen from my stomach to the head. [20] They were generated by my having eaten a lot of fresh [figs].

The context is this: al-Tabarī had just described a number of recipes against warm 
winds (riyāh ḥarrra) nestling in the ear, saying that 'if fresh poppies are in season, their are the most useful thing to eat for this disease, by providing a relief against

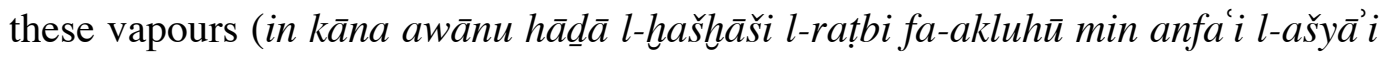
li-hādihi l-illati wa tusakkinu hädihi l-buhārāti)'. Then follows our fragment and afterwards further recipes of things to be introduced into the ear. In other words, the quotation is well framed and appears to be verbatim.

First, we ought to note that al-Ṭabarī quotes from Rufus' 'treatise [maqālatih̄̄] On Preferring Fresh Poppies'. This suggests that at least al-Tabarī thought that Rufus had written such a work and was now quoting from it. Yet, to date, such a title has not come to light in connection with Rufus of Ephesus. Therefore, there is the possibility that the quotation actually derives from Rufus'

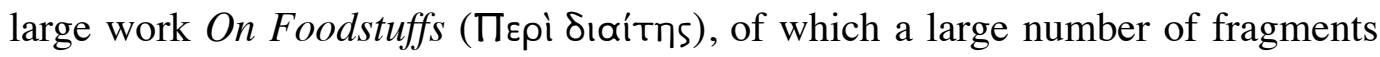
survive. 40 One of these fragment does deal with poppy and comes from Muḥammad ibn Zakarīyā’ al-Rāzī’s Comprehensive Book (al-Kitāb al-Hīwwī), a notoriously difficult source, because he often paraphrases and distorts his predecessors, sometimes beyond recognition, although he also has verbatim quotations. ${ }^{41}$ It runs as follows: 42

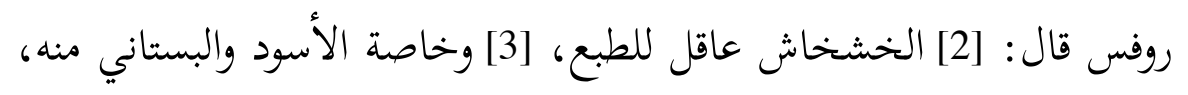

$40 \quad$ See Ullmann (n. 2), 1317 with further literature.

41 U. Weisser, 'Die Zitate aus Galens de Methodo Medendi im Hāầ̄ des Rāzì', in R. Kruk and G. Endress (edd.), The Ancient Tradition in Christian and Islamic Hellenism: Studies on the Transmission of Greek Philosophy and Sciences Dedicated to H. J. Drossaart Lulofs on his Ninetieth Birthday (Leiden, 1997), 278-318; J. Bryson, 'The Kitāb al-Hāwī of Rāzī (c. A.D 900), Book One of the Hāwwì on Brain, Nerve, and Mental Disorders: Studies in the Transmission of Medical Texts from Greek into Arabic into Latin', (Diss., Yale University, 2000); P.E. Pormann, The Oriental Tradition of Paul of Aegina's Pragmateia (Leiden and Boston, 2004), 60-91; O. Kahl, The Sanskrit, Syriac and Persian Sources in the 'Comprehensive Book' of Rhazes (Leiden, 2015).

42 Abū Bakr Muhammad ibn Zakariyā' al-Rāzī, al-Kitāb al-Hāwwī fì l-țibb, 23 vols. (Hyderabad, 11955-70), 20:410, lines 7-15. 


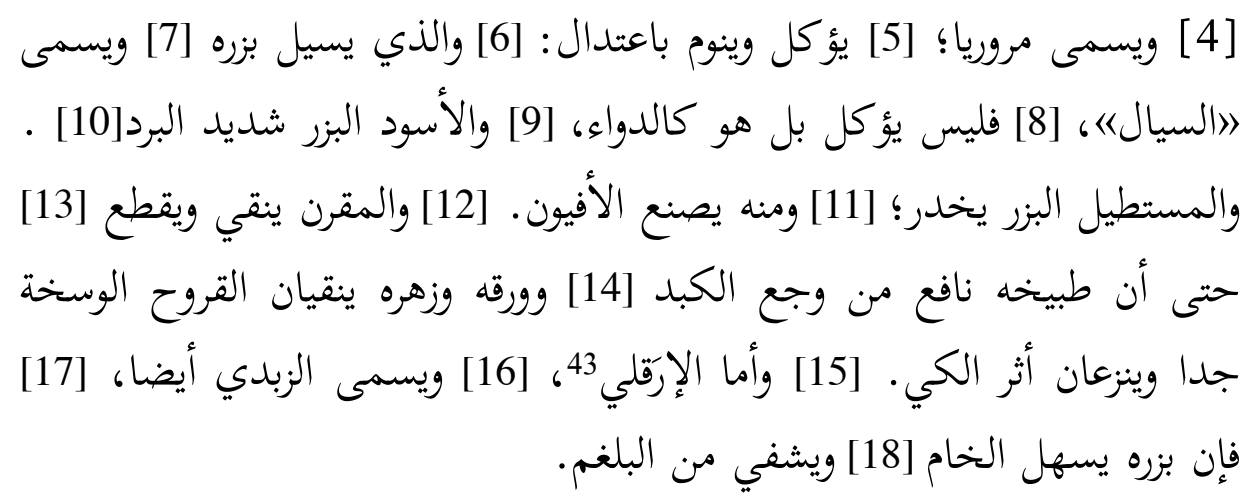

[1] Rufus said: [2] poppies bind nature, [3] especially the black and domestic varieties, [4] called 'passing [murūrē]]'; [5] it is eaten and induces moderate sleep. [6] The variety which has seeds provoking 'flowing' [diarrhoea], [7] called 'the flowing' [al-sayyāl], [8] is not eaten but used like a drug. [9] The variety that has black seeds is extremely cold. [10] The variety that has long seeds has a numbing effect; [11] it is used to make opium. [12] Horned [poppy] cleanses und cuts, [13] so that its decoction is useful against the pain of the liver; [14] its leaves and flowers greatly cleanse impure ulcers and remove cautery scars. [15] The

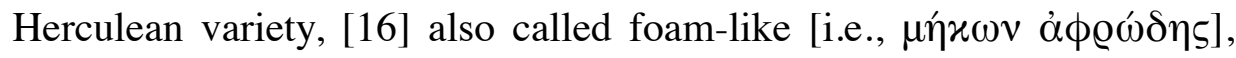
[17] has seeds which ease raw [matter] [18] and cure phlegm.

The information provided here about the 'Herculean variety' ( $\S 15-18$ ), for instance, is a somewhat loose quote from Galen's On Simple Drugs 7.15 (ed.

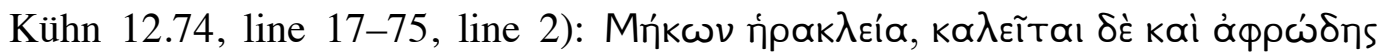
.... каӨ stage whether al-Rāzi is drawing here on Galen rather than Rufus; whether Galen incorporated information found in Rufus; or whether there is a common source.

Be that as it may, let us return to the fragment from the Hippocratic 
Treatments. It constitutes a first-person account of an injury: Rufus was bitten by a snake whilst napping in a garden after having eaten some figs. He finds relief from the severe pain by eating fresh poppy and immersing himself in old water, a procedure which he repeated frequently. Rufus draws the conclusion that the combination of fresh poppy consumption and cold water brought about the easing of the pain. He ends with a remark about sharp vapours that move from the stomach to the brain, owing to what he had previously eaten. We can only speculate how this first-person account fits within a treatise on preferring fresh poppies, about which we know nothing else. The first-person account of this episode fits well with Rufus' tendency to speak in his own voice. 44 Poppy seed and opium were used both in antiquity and the medieval Islamic world, and Rufus' treatise appears to be part of this tradition. 45 This is the first fragment from this treatise by Rufus; it can only be hoped that more fragments, whether in Greek, Arabic or Latin, will come to light and round out our picture of this perceptive and influential clinician.

University of Manchester

P.E. PORMANN

peter.pormann@manchester.ac.uk

$44 \quad$ Sideras (n. 1), 1218-25.

45 See P.G. Kritikos, S.P. Papadaki, 'The history of the poppy and of opium and their expansion in antiquity in the Eastern Mediterranean area', Bulletin on Narcotics (19) 1967, 17-38; S. Tibi, The Medicinal use of Opium in Ninth-century Baghdad, Sir Henry Wellcome Asian Series 5 (Leiden and London, 2006). 